\title{
Gender and charismatic power
}

\section{Paul Joosse $^{1} \cdot$ Robin Willey ${ }^{2}$}

Published online: 01 May 2020

(C) Springer Nature B.V. 2020

\begin{abstract}
Working beyond the inclination to inaugurate alternative theoretical traditions alongside canonical sociology, this article demonstrates the value of recovering latent gender theory from within classic concepts - in this case, Weber's "charisma." Close readings of Weber reveal, (a) tools for theorizing extraordinary, non-masculinist agency, and, (b) clues that account for the conventional wisdom (popular and scholastic) that charisma is "not for women." While contemporary movements may be tempted to eschew charismatic leadership per se because of legacies of dominance by men, there is value in Weber's formulation, which anticipated the performative turn in social theory that would destabilize biologistic gender ontologies. Value in this exchange also flows back to Weber: by confronting his intermittent tendency to describe charisma in terms that we now recognize as "customs of manly power," we reveal heretofore unseen imperfections (i.e., traditionalist modes of legitimation) in his ideal-type. This engagement thus demonstrates an empowering mutuality between contemporary gender theory and "the classics." The article ends by theorising the nexus of gender and charisma in the case of Trump, pointing to possibilities for vitiating Donald Trump's charisma, as well as for anti-Trumpian charisma.
\end{abstract}

Keywords Charisma $\cdot$ Donald Trump · Gender · Politics · Populism · Weber

Myra Marx Ferree and Carol Mueller (2004) advocated for a push beyond shopworn debates about what the women's movement is, outlining instead what it is not -in their words, "not new, not only Western, and not always feminist" (2004, p. 576). Such an expansive perspective is refreshing and welcome. After all, there are few historical

Paul Joosse

pjoosse@hku.hk

Robin Willey

robin.willey@concordia.ab.ca

1 Department of Sociology, University of Hong Kong, Room 902, Jockey Club Tower, Centennial Campus, Pokfulam Road, Hong Kong

2 Department of Social Sciences, Concordia University of Edmonton, Edmonton, Alberta, Canada 
constants as reliable as the erasure of the role and agency of women, and those who would seek to apprehend the women's movement as an "object of study" stand particularly prone to recapitulating a tendency that would examine, so as to minimize (Avishai and Irby 2017)_occluding the force and impact of many while drawing attention to a few. Such dynamics hold on social-theoretical terrain as well: Harriet Martineau, Ida B. Wells, and Jane Addams (among others) are familiar names today because of sedulous efforts to establish their importance in intellectual history (Lengermann and Niebrugge 2006; Thomas and Kukulan 2004). These efforts are of a piece with the larger project of reversing core-periphery distinctions that have also kept theorists of color (e.g., hooks 1981; Morris 2015), and theory emergent from the global south (e.g., Connell 2007a, 2007b) from our view. But as with the women's movement in general, efforts to feminize intellectual history would do a disservice if they remained confined to focussing on exemplary authors who "happen to be women."

The current article works beyond the now-common inclination to decenter the canon and instead demonstrates the potential for drawing analytical power from latent gender theory that calls out sotto voce from within classical constructs - in this case, Max Weber's "charisma." The animus behind this move is the contention that attempts to inaugurate alternative traditions alongside "the intellectual patrimony of the MarxDurkheim-Weber trinity" (Murray 1996, p. 13), laudable though they are, still leave sociological fathers - and canonical sociology with them - untouched as paragons of relevance. This perpetuates the masculinization of social theory in a number of ways. First, by refraining from moving beyond "decentering," we effectively consign gender researchers to an interminable, onerous, and needlessly adversarial relationship with all of what is usually regarded as classical theory - an asymmetrical and unenviable conflict, given the formidable legacy that "the fathers" continue to enjoy. Second, by regarding classical sociology as being inconsequential for, or off-limits to, those who would otherwise benefit from it, gender scholars, constrained by the presentism of "contemporary theory," are subjected to increased labor; left with the task of inventing new theoretical tools in cases where the classics may still be useful. Again, this may be a perilous position in a discipline for which turning to the past is often an epistemic requirement. ${ }^{1}$ Third, an oppositional posture toward the classical canon forecloses the possibility for what is intended with this article - namely, the establishment of an equitable mutuality with the sociological fathers themselves. Such an arrangement would allow contemporary scholars to work back upon and improve classical formulations, pushing against whatever limitations may have been endemic to the subject positions of their authors. ${ }^{2}$

All bids for such a relationship will no doubt be fraught with tension, but this should not mean that they are without value. An ambivalence between asymmetry and mutuality is apparent, for example, in the reflections that preface Roslyn Bologh's (1990, p. xv) Love or Greatness: Max Weber and Masculine Thinking:

\footnotetext{
${ }^{1}$ As Lewis Coser (1981, pp. 181-182) noted long ago: "Were sociology a cumulative discipline, as say physics, it would be hardly necessary for practicing sociologists to study the classics.... But such cumulation has not yet occurred in sociology; moreover one may legitimately doubt that it will occur in the foreseeable future or ever... As long as this is the case ... recourse to the classics will continue to be necessary."

${ }^{2}$ It must also be noted that two of the three members of the aforementioned trinity (Durkheim and Marx) were Jews in a largely Christian and anti-Semitic Europe. As such, we should not be so surprised if we were to find indications of sensitivity, even within the classics, to what we would today call "positionality."
} 
I do not claim that my sight is better than his. My own scope is much smaller, tiny in comparison with the magnitude of his. Nevertheless, because he has given me a gift of his vision, I can now look beyond and say, 'Max Weber, your vision is limited; we live in different bodies, in different times, and we come from different places. Your vision, extensive and expansive as it is, is the vision from your body inscribed with your gender, your place, your time. It may be the vision that enables you to make your way in and through the world; but it also restricts what you can see, what you can experience and what you can know.... And so I struggle against it; I reread your writings and scrutinize your way, in order to carve out a way for myself.'

Bologh thus both acknowledges her debt to Weber's efflorescent social-historical compositions while sounding out a note of her own, working to complement and extend his theory-subject to whatever criticism it also deserves. As a model for interaction, this approach implies an ongoing iterative process whereby contemporary theorists reflexively interact with and improve upon formulations from the past.

Weber's "charisma" presents a good case for illustrating such interventions because it is relevant to issues of power and mobilization that are of concern for contemporary movements, and because it has been subject to the above-mentioned processes of masculinization in a number of ways. For instance, there is a palpable unease amongst charismastudies specialists that pertains to categorical issues about what "counts" as charismaspecifically the fear that the term has been, "debased to mean something much closer to what used to be called ... 'star quality"' (Baker quoted in Derman 2012, p. 214; also Eatwell 2002; Rieff 2007; Smith 2000). The ancient Greek term has indeed experienced a remarkable popular uptake since Weber reintroduced it (Kemple 2014), and in reaction, scholars have sought to prevent loose usage, erecting strong distinctions between what is "truly" charismatic and what is "mere celebrity" or "idolatry" (see Smith's 2013, pp. 26-32, critical discussion of "pseudocharisma"). As laudable as the desire for conceptual precision may be, this boundary work risks capsulizing charisma within an anachronistic gender paradigm, reifying demarcations between "serious" (read: masculine) and "frivolous" (read: feminine) forms of cultural power. As Tracey Whalen (2014, p. 10) notes:

[T]he gatekeeping of distinctions between charisma and celebrity is problematic: not only are the lines between the two increasingly permeable in twenty-first century public life, but the contributions of women (often artists, actors, and musicians) tend to be undervalued as a result.

Such observations seem all the more apt in the wake of the election of a celebrityPresident who consistently made use of sexism in political messaging and who revealed the charismatic potential that is nascent within the fusion of politics and celebrity culture into "infotainment" (Joosse 2018a, 2018b; Lukes 2017; Moy et al. 2005; Thussu 2008; Wagner-Pacifici and Tavory 2017).

As a result of this dynamic, social movement activists who could be expected to oppose someone like Trump are at times left with the feeling that charisma simply is "not for them." This is not least because progressive social movements themselves have bequeathed us with their own "great man theories of history" that tend to exaggerate the importance of a few (invariably male) leaders. As Ruth Milkman repeatedly noted in her 2016 Presidential address to the American Sociological Association, organizers and participants of Occupy 
Wall Street and Black Lives Matter "reject outright the civil rights movement's historic reliance on charismatic leaders, the vast majority of whom were male" (2017, pp. 23, 11-12). Also speaking about Black Lives Matter, Political scientist Cathy J. Cohen similarly criticized Al Sharpton for coming "out of a tradition, an ideological positioning, that would lead him to seek the role of the male charismatic leader" (Cohen and Jackson 2016, p. 3). Cohen goes on to suggest that,

many of the young leaders in the Black Lives Matter movement recognize that the male charismatic leader, or the singular charismatic leader, is not the form of leadership that they adhere to or they are going to put forth (Cohen and Jackson 2016$, p. 15$){ }^{3}$

In contemporary political debates, therefore, it seems that masculine dominance and charisma are frequently seen as synonymous. The mobilizing potential for nonmasculinist forms of charismatic agency is thus apparently going unconsidered.

This process illustrates a social-theoretical truism: the nature of our concepts determines what can be thought. Moreover, histories are not merely sets of "recollections about the past." They are receptacles for narratological (and therewith projective or teleological) content that recursively gives rise to expectations about the future (Olick and Levy 1997; Tavory and Eliasoph 2013). The limits that "what has been done" impose on "what can be imagined," can thus account for knowledge-production processes uncovered by Shilpika Devarachetty (2012, p. 92) who recently found that, among 118 articles on charisma published in the administrative science journal Leadership Quarterly, only $8 \%$ of examples of charismatic individuals were women.

The core aim of the current article, then, is to demonstrate the possibility for a sociological "re-imagination" of charisma — one that provides conceptual tools that will both (a) be useful for theorizing beyond masculinist agency, while also being (b) fully "classical," in the sense of remaining true to the underlying principles that Weber was seeking to convey in his original formulation. Ultimately, the contention will be that, in addition to adding value to contemporary gender scholarship, the benefits will also flow back to Weber himself, rendering a "charisma" that is more perfectly "Weberian" than even Weber's original descriptions were able to be. The article ends with a consideration of the charisma of Trump, arguing that his brand of domineering sexuality is incidental to his charismatic power, and pointing to possibilities for charismatic challenges to Trump's presidency.

\section{Nasty, brutish, and short: Weber's charisma as primordial masculinity}

"Charisma" is not completely absent within gender scholarship. Prior engagements, however, typically have taken the form of applications of Weber's concept to the women's movement in general (Baker 1982; Reger 2002, pp. 722-724), analyses of specific contexts that have been propitious for charismatic women (Agadjanian 2015;

\footnotetext{
${ }^{3}$ Referencing this legacy within the civil rights movement, Harvard political scientist Brandon Terry (2018) recently leveled criticism at Martin Luther King himself, noting that, "King's blindness to the gendered dimensions of charismatic authority and hierarchical leadership within protest organizations - and the black church - is surely reason enough to be critical of his example."
} 
Chong 2008; Finlay 2002; Lawless 1993; Van Osselaer et al. 2020), or descriptions of "charismatic masculinity" as it manifests in contemporary religious and political movements (Joosse 2018a; Wallis 1982; Wignall 2016; cf. Lerum 2004). As yet, however, there have been no in-depth exegeses of Weber's original texts on charisma through the lens of gender-something one would expect to be an informative, if not necessary, precondition to assessing the concept's viability for understanding contemporary power relations. In this section, we therefore engage in a close reading of Weber's descriptions of charisma, before demonstrating how contemporary theoretical approaches can enhance, complicate, and undermine "charisma" as a gendered form of social power.

Even though "charisma" bears more responsibility than perhaps any other concept for Weber's eventual canonization within American sociology (Derman 2012), and even though there has been a resurgence of interest in charisma at the center of the discipline (e.g., Abrutyn and Van Ness 2015; Alexander, 2011; Hochschild 2016; Joosse 2017; Joosse, 2018a, b; Lukes 2017; Reed 2013; Smith 2013; Wagner-Pacifici and Tavory 2017), it is something that took on central importance for Weber himself only in the last decade of his life; his main descriptions appearing in writings that would be published posthumously as Economy and Society (1922a, b[1978]), in Die Wirtschaftsethik der Weltreligionen, a corpus of work he produced on the religions of China (1915[1958]), India (1916[1958]), and ancient Judaism (1919[1952]) (especially in an introduction to that work, published later as The Social Psychology of the World Religions [1946a]), and, to a lesser extent, his Beruf lectures on science and politics (1917 and 1919, respectively). In the third chapter of the second draft of Economy and Society, he tabled his oft-cited definition:

The term 'charisma' will be applied to a certain quality of individual personality by virtue of which he is considered extraordinary and treated as endowed with supernatural, superhuman, or at least specifically exceptional powers or qualities. These are such as are not accessible to the ordinary person, but are regarded as of divine origin or as exemplary, and on the basis of them the individual concerned is treated as a 'leader' (Weber 1922a, p. 241).

A quick indication of the salience of gender in the passages that accompany this definition are the exemplary figures he uses to illustrate the concept. In all, eighteen persons are mentioned by name, and although they vary greatly in terms of their sphere of action, their historical emplacement, and even their empirical facticity, they are all men. ${ }^{4}$ Beyond this blunt headcount, Weber's original descriptions of charisma are inextricably tied to hegemonic forms of masculinity, being most classically present in competitive, male-centric social contexts that are geared toward producing "winners" and "losers." It attends, for example, to those who are successful "in the hunt or heroes

\footnotetext{
${ }^{4}$ These include: Mormonism founder Joseph Smith, Bavarian revolutionary Kurt Eisner, Napoleon, writer Stefan George, Israelite Kings Saul and David, the Israelite Judge Jephtah, prophets Jeremiah and Isaiah, Daniel and Enoch, Irish legend Cuchulain, Homer's Achilles, Francis of Assisi, Jesus, mathematician Karl Weierstrass, journalist and financier Henry Villard, and Caliph Omar.
} 
of war" (1922a, pp. 241, 1119) and those who use "the war dance" to produce a "mixture of fear and fury before the battle" (p. 406). It is accrued by kings, conquerors, and brawny legends like Samson and Achilles (1952, p. 411; 1922a, p. 1112). Weber illustrates charisma with "berserk" warriors and "men endowed with the charisma of fighting frenzy" (1922a, pp. 242, 1112). In ancient China, charisma was the social glue for a "fraternity of young warriors"-occupants of the "bachelor house ... of the (charismatic) warrior chieftain where diplomatic transactions (such as the surrender of enemies) were consummated, where weapons were stored, and trophies (cut-off ears) were deposited" (1951, p. 24). At one point, he even writes in a manner that anticipates Gilbert Herdt's (1987) descriptions of Sambian warrior production rituals: in the "“men's house," "5 Weber writes, "an individual who has not successfully gone through the initiation remains a 'woman'; that is, he is excluded from the charismatic group" (1922a, pp. 249-250, 1144).

In these descriptions it is clear, therefore, that charisma appears as a masculine property and its bestowal is tantamount to masculinization. A "winner" in the contexts Weber describes is a man who demonstrates an ability to vanquish foes, and insofar as this individually-demonstrated power inspires compatriotism within a group, charisma is the symbolization of one man's ability to lead his group in acts of dominance over another, correspondingly masculine, group. The occlusion of women in this vision of charismatic power is therefore programmatic: because "war and sport" (and, in Weber's more contemporary applications, politics [1922a, pp. 242, 263]) were conceived as masculine domains, women are not even in the field of play, their subordinate status so much taken for granted as to go unmentioned. This data incognita status for women persists across all of Weber's writings on charisma, save for one location in The Religion of India (1958, p. 49) where they are excluded in more explicit terms:

[i]n contrast to the hereditary chieftain in times of peace who, among some tribes, could also be a woman, the warrior king and his men were heroes whose successes had proven their purely personal and magical qualities. The authority of the war leader, like that of the sorcerer, rested upon strictly personal charisma (emphases added).

The "times of peace" mentioned in this passage offers a clue as to why Weber felt the need to render "charisma" in such muscular terms. "Peace" is a time of habit-formation, of routinization, of regularized offices that-because they need not be legitimated through personal impressiveness - "even women" may inhabit. Charisma is, for Weber, the opposing principle that places all such offices under threat. Thus, here we have a tie-in to his larger tripartite division of social power, involving the "traditional" and "rational-legal" forms of domination (Herrschaft) that stand alongside charismatic power (1922a, pp. 212-216). For Weber, traditional and rational-legal authorities are both ontologically "societal" in the sense that their medium of instantiation is preestablished and shared cultural forms (customs and recognized rational principles, respectively). Charisma, by contrast, is always "specifically foreign to everyday routine structures," and it arises from the sub-societal realm as a function of personal devotion

\footnotetext{
$\overline{5}$ This is a military form of cohabitation found in many cultures.
} 
(1922a, p. 246). ${ }^{6}$ Insofar as charisma constitutes a rebuke to accepted social norms, it is thus something that draws men back into primordial, and even "pre-social," circumstances.

This is not just a recapitulation to social arrangements "when men were men," however. For Weber, it extends further, beyond the social contract of patrimonialism and into the extremities of a Hobbesian vision in which men are beasts. Charisma is "naturalistic rather than symbolic"; it is evident in "primitive circumstances," as something that is increasingly salient "the further we go back into history" (1922a, pp.406, 241, 1111). It is an outflow of "personal strength" that attends to "'natural' leaders" (1922a, pp. 1114, 1111). When the Ark of Yahweh arrives in the war camp after victory, the ancient Israelites descend from ritualistic purity into charismatic fervor, partaking in the "eating of raw flesh and drinking of blood" (1952, p. 94). Also telling of this staging is Weber's frequent recourse to animalistic imagery. We read of the "berserk warrior" whose countenance is "like a mad dog, before rushing off in a bloodthirsty frenzy" (1922a, p. 1112; also 1952, p. 44), of charismatic " "blonde beasts" ", who are "kept like war elephants" in Byzantium (1922a, p. 1112, 242). Even the "Bull of Apis" (a bovine signifier of the Pharaoh's strength) is used to illustrate the principle of charisma (1922a, p. 247).

This depiction of a bestial past is mirrored, in turn, by the removal of competitive ferocity in Weber's vision of the modernist future. In this connection, it is important to note the influence of a Nietzschean masculinism on Weber's thought. At the end of the Protestant Ethic and the Spirit of Capitalism (1905), Weber contemplates a "last stage" of bureaucratic development, populated by Nietzsche's (1885[2008]) "last men"those who have been tamed to the point of giving up on life and all its strivings. ${ }^{9}$ For Nietzsche, these "last men" contrast with the Übermensch- "overmen" who "appear as symbols of repudiation of any conformity to a single norm: the antithesis of mediocrity and stagnation" (Kaufmann 1974, p. 309). Shortly after the reference to one predecessor, Weber turns to another, quoting a lamentation from Goethe ${ }^{10}$ in his description of a future of deadening "mechanized petrification" in which heroics are no longer possible:

No one knows who will live in this cage in the future.... For the last stage of this cultural development, it might well be truly said: 'Specialists without spirit,

\footnotetext{
${ }^{6}$ As Bendix (1960, p. 300) noted, charisma implies "a degree of commitment on the part of disciples that has no parallel in the other types of domination."

7 The term is thought by some to mean "bear-fighter" and in Germanic/Norse tribes the fighter would either be bare-chested or be draped in bear skins as they rushed into battle.

${ }^{8}$ Nietzsche's influence on Weber, which is explicit here, is discussed below. The "blonde beast" is Nietzsche's expression for a predatory, lion-like "hidden core [that] needs to erupt from time to time, the animal has to get out again and go back to the wilderness." Contrary to later racialist interpretations, Nietzsche is careful to state that "blonde" does not refer in any way to racial difference, but rather to the lion-like energy that threatens to erupt from any culture: "the Roman, Arabian, Germanic, Japanese nobility, the Homeric heroes, the Scandinavian Vikings," Nietzsche writes, "- they all shared this need" (Genealogy of Morals, pp. 476-477).

${ }^{9}$ Nietzsche offered fierce critiques of the modern bureaucratic state, along with the moral systems espoused by Schopenhauer, Buddhism, and Christianity, which he thought were nihilistic and life-denying. For a fuller discussion of Nietzsche's influence on this passage, which Parsons's translation completely misses, see Kent (1983).

${ }^{10}$ Nietzsche himself viewed Goethe as an approximation of the Ubermensch (Twilight of the Idols, p. 49; Kaufmann 1974, p. 316).
} 
sensualists without heart; this nullity imagines that it has attained a level of civilization never before achieved' (1905, p. 182). ${ }^{11}$

Charisma, so often associated in what he called its "pure" or "genuine" form with magic (e.g., Weber 1922a, pp. 142, 241-244, 248-249, 1111-1112, 1134, 1142-1143; 1946b, p. 139; 1951, pp. 29-32; 1958, pp. 58, 198, 335-336) is thus all but banished in his "disenchanted" (translated alternately as "demagicalized" [Schluchter 1985, pp. 9697]) world, and the erasure of personal distinction through the submission of the individual to an impersonal rational order thus represents at once both a terminal diminution of charisma in the modern world and a neutering of "Man's" creative will-to-power.

Although less explicit, a Nietzschean masculinity also seemed to inform Weber's theory of charismatic actualization. Specifically, the notion that "[a] living thing seeks above all to discharge its strength" (Nietzsche 1886, p. 211) is echoed by Weber's depictions of charisma as a "heroic frenzy"- a transient display of personal glory that only ever exists, Weber stresses, "in statu nascendi" [in the process of being formed] (1922a, p. 246). This flash-in-the-pan quality accounts for why Weber spends the lion's share of his discussions of charisma in Economy and Society describing "routinization" (1922a, pp. 1121-1148) - the dissipation of charisma's original energy and its transformation into traditional or rational-legal forms of social power. Like the brutal logic of a boxer's career, charisma is fleeting, constantly vulnerable to falsification, and under an unremitting demand for "proofs" (1922a, pp. 242-244, 266, 441). Such romantic notions of perilous self-expenditure align, in a counter-pose, with traditional gender norms pertaining to the more feminine "nesting instinct" that values selfpreservation (Beck-Gernsheim 2002; Hayes 1996). ${ }^{12}$

Thus, we can see that, both at macrohistorical scales (in terms of the unfolding of modernity), and at the micro-interactional level (in terms of individual struggles in life), an important subtext to Weber's theorization of charismatic power is the story of a tragic masculinity - a masculinity that is wild, disruptive, and perennially under threat. ${ }^{13}$ In Weber's metatheoretical vision, the power of charisma consists of futile, back-spiralling eddies that muster only transitory victories against the ongoing flow towards what has been variously called "bureaucratization," "disenchantment," and "routinization" - but that is also, in an important sense uncovered here, a form of domestication. ${ }^{14}$

\footnotetext{
${ }^{11}$ Compare this passage, for example, with Nietzsche's similar laments in The Gay Science, section 206.

${ }^{12}$ See Beyond Good and Evil: "Above all, a living thing wants to discharge its strength-life itself is will to power; self-preservation is only one of the indirect and most frequent consequences of this" (1886, p. 211). ${ }^{13}$ See Falco (1999) for a helpful discussion of thematic mutuality between charisma and tragedy.

${ }^{14}$ See Weber's description of the "family-less organization" of the ancient Benjamites and Bedouins, which grows not by domesticating men, but rather through "marriage by abduction"- something that is, for Weber, "pure charismatism" (1952, pp. 43-44). "Homemaking" themes seem salient also in Weber's remark that, "[e]very charisma is on the road ... to a slow death by suffocation under the weight of material interests: every hour of existence brings it nearer to this end" (1922a, b, p. 1120).
} 


\section{Confluences with contemporary theories of masculinity}

If we were to update these descriptions with more contemporary theoretical terminology, we might therefore say that the gendered aspects of Weber's charisma are manifestly resonant with what Raewyn Connell and colleagues would later call "hegemonic masculinity" (Connell 1987; Connell and Messerschmidt 2005). Like Weber's approach to "charisma," Connell establishes her concept in eminently relational terms. That is, the masculine hegemon is not a standalone entity, but rather something that is "always constructed in relation to various subordinated masculinities as well as in relation to women" (Connell 1987, p. 183). Where Weber uses the notion of "legitimacy" to distinguish charismatic domination from subordination by brute force (1922a, pp. 213215), Connell draws from the Gramscian notion of "ascendency" in that hegemonic masculine forms are not primarily instantiated through violent coercion, but rather through dialectics of comparison which subordinate, rather than eliminate, alternative masculinities. ${ }^{15}$ Thus, while the majority of men cannot exemplify the hegemonic ideal, their performed dissimilarities vis-à-vis such an ideal nevertheless contribute to the production of a graduated scale of masculinity in which all men - including those who do not fully "measure up"- benefit from a vector of ascendency over women (Connell 1987, p. 184). This, in turn, corresponds to the manner in which women are excluded, pro forma, from the field of play in Weber's descriptions of charismatic competition.

A crucial difference, however, is that while Weber intermittently seems to indicate that he thought processes of masculinist distinction were disappearing, more contemporary theorists have asserted their continued relevance, beginning with Goffman, who gave a vivid depiction:

In an important sense there is only one complete unblushing male in America: a young, married, white, urban, northern, heterosexual, Protestant, father, of college education, fully employed, of good complexion, weight and height, and a recent record in sports.... (Goffman 1963, p. 128).

This ongoing enchantment with male heroics is thus a contributor to the waning plausibility of Weber's (and most of classical sociology's) prognostications about secularization (Berger 1996; Hadden 1987).

But Weber's limitations as a seer are not so relevant for present purposes as is the common etiological theory that exists - across the classical/contemporary divideabout the emergence of masculine power. Like Weber's charismatic hero, Goffman's (-cum-Connell's) "ideal man" is widely recognized, but necessarily rare. The relational nature of such an ideal becomes clear when one contemplates the implied counterimage to both Weber and Goffman's descriptions: all those "blushing males" who exist in subordinate positions within hierarchies of gender. Weber's failed men's house initiate who "remains a "woman" (1922a, pp. 249-250) has its counterpart in Goffman's suggestion that "[a]ny male who fails to qualify... is likely to view himself - during moments at least - as unworthy, incomplete, and inferior" (1963, p. 128). Realizing this complementarity between classical and contemporary concepts thus allows us to grasp more fully the continuity of the gendered dynamics of

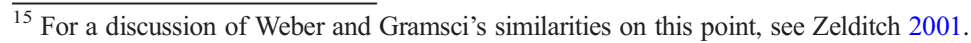


extraordinary (read: charismatic) power as they have been expressed, with varying degrees of explicitness, in the history of social theory.

\section{The political was also personal: Weber's normative evaluation of charisma}

Given his original descriptions, one's assessment of Weber's personal estimation of charisma-i.e., whether he thought charisma was a "good thing"-stands to color dramatically what conclusions one is apt to make about his gender politics. For some, like Wolfgang Mommsen (1959[1984]), Weber was thought to have personally "yearned" for Germany's charismatic release from the bureaucratic morass of modernity. In this view, which tends to be shared by those who focus on the lamentation at the end of The Protestant Ethic rather than on the more hard-boiled tone of Economy and Society, Weber becomes blameworthy, not just for giving energy to a political climate that culminated in Hitler's rise, but also as someone who strove romantically toward brutish forms of masculine domination more generally (Potts 2009, p. 129). Thus, while philosophers like Dorothy Emmet warned of "something rather Teutonic, suggesting the Führer-Prinzip" in Weber's descriptions (1958, p. 233), and while former students like Carl Schmitt were decried for their association with Nazism (Engelbrekt 2009), others like anthropologist Charles Lindholm have noted that the study of charisma since Weber has been "unfortunately quite male-centered.... because of a male bias in the theoretical and popular models" (1990, p. 6).

One obstacle to voicing such moral assessments with a definitive tone, however, is that Weber's pretentions toward "value-neutrality" (Roth and Schluchter 1979, pp. 65-116) have had the effect of obscuring his personal political commitments, leaving them open to a range of interpretations. Be that as it may, there are indications that Weber's views on charisma were more complex than Mommsen's influential suspicions would suggest. ${ }^{16}$ First of all, if we are to prioritize the importance of the two abovementioned works (PESC and $E \& S$ ) for charisma scholarship, then without question more weight should be allocated to the lengthier, more explicit, and more didactic descriptions of charisma in $E \& S$ (1922a, pp. 241-254, 1111-1157) than to the passing mention in PESC (1905 [1920], p. 178). With this prioritization in hand, we can note that, if Weber is to be suspected of "hoping" for a great leader in PESC (1905), then E\&S, which was written in the latter half of the 1910s, shows him cooling to the possibility of "new prophets" during the very moment when the humiliation of Versailles was giving impetus for many in his own milieu to begin flirting with "strong personalities" on all sides of the political spectrum. Weber succumbed to Spanish flu in June 1920, and therefore never had an opportunity to comment on the man who that same year took the reins of a small but virulent National Socialist party. His assessment of Kurt Eisner, ${ }^{17}$ however, as someone who became

\footnotetext{
${ }^{16}$ In a recent example of Mommsen's continued ability to project a prejudicial hostility toward "charisma" in contemporary scholarship, Zeitlin (2019, pp. 146-149) relies on four block quotes from Mommsen to level his own critique, without citing any of Weber's own writing on charisma. At the same time, he inexplicably tells the reader that "a careful examination of Weber's writings reveal that he viewed charismatic leadership in a purely positive light" (p. 147). In fact, Weber expends great effort to distance himself from such a position (Joosse 2014, p. 274).

${ }^{17}$ The socialist leader of the ill-fated Bavarian revolution of 1918 .
} 
"overwhelmed with his own demagogic success" (Weber 1922a, p. 242), is perhaps telling of the stiff repudiation that we might have expected from Weber, had he lived to witness Hitler's manic self-importance. ${ }^{18}$ Further, in an incisive review of Weber's development of the concept, Peter Baehr (2008) has shown that Weber's interest in charisma sprung originally out of a concern with what he called the "Caesarist" danger that haunted German politics ever since Bismarck (pp. 11-114).

This "concerned analysis" would thus position him in the very least as someone who was wary of charismatic politics, and perhaps as a forbearer standing in lineage with the likes of Theodore Abel (1937) and Hans Gerth (1940) who later employed "charisma" in early efforts to decode (with the clear hope of vitiating) the "Hitler movement." Thus, while Weber assiduously maintained a separation between his "value-free" theoretical postulations and his political or personal commitments, the factors above suggest that there is some support for Smith's recent conclusion that - the pessimism about modern bureaucracies notwithstanding - Weber was "hostile to charismatic politics" (2013, p. 53, n.7).

Turning from the political to the personal, this perspective also squares more convincingly with what we know about the circumstances of Weber's family life. Weber's fall-out with his father over the latter's harsh treatment of his mother is well known (Roth 2001, pp. 527-536), as is his support for Marianne Weber's efforts within Germany's nascent women's movement (Thomas 1985). His reputedly unconsummated marriage with Marianne, in which he seems to have treated her in accordance with a Quaker ethic of mutual responsibility and respect (Kent 1985) would seem to exemplify a more equitable alternative to the sexually-domineering "headship" that has so often characterized the fraught domestic sphere. Such a "progressive"19 stance with respect to the place and role of women in his personal life would be odd in someone who desired a return to charismatic modes of social organization-at least in the terms that he used to describe them. Moreover, Weber seems to have held to his ethical commitments categorically, irrespective of how remarkable any particular individual might be. As Marianne wrote in her biography, Max "did not accept the idea of a special 'morality of genius'.... he stood his ground when such discussions arose: what is 'sin' for Muller and Schulze (Smith and Jones) must be so for Goethe" (Marianne Weber, 1926, p. 155). Thus, while there is undoubtedly a romanticism in Max's depiction of how charisma functions, he seems to have been incredulous toward, and wary of, the "deliverance" that some saw in the promise of charismatic domination in the private and public spheres, and unlike Nietzsche, he seems to have been immune (or perhaps "unmusical" 20 ) to personal fascinations with strong, singular leaders. ${ }^{21}$

\footnotetext{
${ }^{18}$ Weber's support for Georg Simmel also indicated his opposition to anti-Semitism (see Gerth and Mills 1946, p. 43).

19 This is not to equate sexlessness with progressivism.

${ }^{20}$ Weber uses the term "unmusical" twice to describe those who are not subject to charismatic fascination in The Social Psychology of the World Religions (1946a, pp. 287, 289). The term was used most famously, however, when Weber referred to his own irreligiosity in a letter to Ferdinand Tönnies: "For I am indeed absolutely 'unmusical' and have neither the desire nor the capacity to erect some such spiritual 'edifice' of a religious type in me - that simply is not possible, indeed I reject it."

${ }^{21}$ Nietzsche's fascination with "philosophers, artists, and saints" (Nietzsche 1876, bk. 3, sec. 5) was emotional, visceral, and tempestuous, as evidenced by his worshipful-then-contemptuous feelings toward Richard Wagner (Nietzsche 1872, pp. 31-32, sec. 16-25, pp.99-144; 1888), Schopenhauer, Socrates, Napoleon, and Goethe, and others.
} 
Irrespective of his own stance toward the concept, however, we have shown how Weber's original presentation of charisma reproduces an anachronistic gender paradigm - one that naturalizes a biologistic foundation for men's domination of women. As such, some theoretical elaboration and interpretation is needed if we are to refashion "charisma" for contemporary use. A salvaged conception of charisma would need, in other words, to do more than the "current writers on charisma [who simply] take care not to reproduce gender-biased images in their texts" (Jermier 1993, p. 231). Figures like Joan of Arc, Mary Baker Eddy, Mother Theresa, Vandana Shiva, and Oprah Winfrey attest to the empirical existence of charismatic women, ${ }^{22}$ but under what conditions might a Weberian theorization of their power be possible? Rather than skirting the issue of gender, the task of theorizing gender in charisma scholarship needs to be faced head on.

\section{Discussion: Reimagining "charisma" for analyses of gendered power}

The remainder of the article considers two contemporary debates within charisma scholarship and uses the parameters of these debates to argue for a conception of charisma that will enable a more theoretically sophisticated approach to gendered power. The first debate pertains to how much we should accept of the previouslydescribed primordialism and naturalism in Weber's descriptions. When faced with his intermittent tendencies in this direction, we argue for a selective reading of Weber that draws heavily from a series of statements he makes that are suggestive of a countervailing proto-interactionism in his work. The second debate deals with Bourdieusian reinterpretations of Weber that imagine charisma as a form of symbolic or cultural capital. While acknowledging the importance of Bourdieu's attempt to theorize charisma's cultural dimensions, we draw on critics who caution against a Boudieusian cultural-determinism that would diminish the revolutionary, entrepreneurial, antinomian, and otherwise "specifically exceptional" nature of charismatic agency, about which Weber is consistently intentional in his descriptions of charismatic processes.

By charting a course between these two possibilities - either conceptions of charisma that would imply a naturalistic gender ontology or those that would denote cultural circumscription and determination-we can release the latent potential for Weberian theorizations of non-masculine charismatic agency. We end with a consideration of how these insights can help with theorizing charisma in the time of Trump, imagining the tactical possibilities for political performance that could capably counter Trump.

\section{Warding off the naturalistic fallacy}

In 1971, Pierre Bourdieu picked up on a duality in Weber's writing, suggesting that even though he "occasionally succumb[ed] to the naïve representation of charisma as a ... gift of nature" (1971, p. 129), he also gives "a representation of the relations between religious agents that may be termed interactionist (in the sense in which we speak today of symbolic interactionism)" (ibid., p. 121, emphasis in the original). Thus, while some

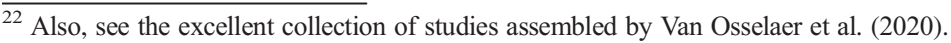


like Parsons (1963, p. lxxiii) have pointed to an individualistic "trait atomism" in Weber's descriptions, Bourdieu draws our focus toward a social etiology for charisma that is inherent in Weber's formulation. Indeed, Weber prefigures the Bourdieusian (1984) precept that recognition is the coin of the realm in value hierarchies when he maintains that "it is recognition on the part of those subject to authority which is decisive for the validity of charisma" (Weber 1922a, p. 242). Further in this vein, Weber notes that charisma is "an extraordinary quality of a person, regardless of whether this quality is actual, alleged, or presumed" (ibid., p. 295) - a proleptic formulation of the Thomas theorem, which emphasizes, again, that recognition is key. ${ }^{23}$ Thus, while Meredith McGuire, in her Presidential address to the Association for the Sociology of Religion, lamented that the phrase from his definition, "quality of individual personality" (Weber 1922a, p. 241) "sent generations of sociologists off on a non-sociological tack" (1983, p. 6), this was not so much an indictment of Weber himself, as it was a criticism of the "generations" - those who, unlike McGuire, either read Weber uncarefully or never bothered to read beyond the oft-quoted definitional passage.

So while Weber appears to leave the door unsatisfactorily open to primordialist, naturalistic, "traitist," and otherwise essentialist readings of charisma, there are clearly countervailing themes in his work that also deserve consideration. If, as this article intends, the goal of looking for and salvaging the use-value of classical sociological concepts is a legitimate one, then it is our prerogative to confront and repudiate the tendencies for which Weber has been much-criticized with affirmations of his statements that imply a Weber who thought differently — a Weber who described a socialinteractional etiology for charismatic power (Joosse 2014).

This selective emphasis is important because it opens up the possibility for a critical appraisal of the constraining nature of acculturated, gendered expectations during charismatic acclamation. That is, once one recognizes that charisma is a social relationship rather than a natural trait, it follows that one should also view it as something that is mediated by discursive figurations of authority that cleave to particular macrohistorical structures and that manifest at the micro-level as particular sets of expectations and repertoires for followership (Bourdieu 1987, 1991).

That Weber would be limited in his ability to recognize these cultural inscriptions upon gender should not surprise us. He wrote before twentieth-century social theorists deliberately undertook the task of "denaturalizing" gender and sexuality, revealing them to be mutable, historically contingent, and performatively maintained (de Beauvoir 1949 [1972]; Butler 1990; Foucault 1976[1990]; West and Zimmerman 1987). Had he possessed an awareness of this ontological destabilization that was in the offing, however, he would have been sensitized to the need to be on watch for how his descriptions of "'natural' leaders" (1922a, p. 1111) might actually contain more than a helpful share of content that we can now recognize as mutable cultures of gender and sexuality. Indeed, his own use of "scare quotes" around the term "natural" in the previous sentence is suggestive, if not of an anticipation of this later scholarship, then at least of the type of critical inquisitiveness that would serve as a precondition to it. Similarly, his comment that an unsuccessful initiate to the men's house "remains a "woman" (note the scare quotes again) indicates a non-

\footnotetext{
${ }^{23}$ When speaking of the "'greatest' heroes, prophets, and saviors," he is careful to add the caveat that these are only such "according to conventional judgments" (ibid., 242, emphasis added).
} 
essentialist sophistication with respect to viewing gender as a socially-mutable (rather than biologically-fixed) category. ${ }^{24}$

Writing before the aforementioned developments in gender scholarship, however, Weber lacked the theoretical language that would have enabled him to articulate what awareness he seemed to possess already about the complicated interactions among biology, gender, and sexuality that were salient within the examples he was using. But if one were to equip a Weberian theory of charisma with benefits derived from later interactionist and performative approaches to social theory, then it becomes possible to pry open analytical space between what we might consider the "spirit" of Weber's charisma (as a form of authority that is distinct from tradition and bureaucracy) and the masculinist examples that he draws upon for his illustrations (which seem to perpetuate a naturalistic gender ontology). That is, to the extent that his examples of charisma reproduce what we can now recognize as "customs of manly power," we can see how they represent an imperfection within Weber's ideal type itself - in the form of an entry of traditional modes of legitimation. This newly-obtained clarity thus provides the dual benefit of achieving a more perfect fealty to the Weberian ideal-type of charisma (namely, as a type of authority that is intended to be distinct from tradition), while also construing it in a way that makes it more amenable for describing non-masculinist iterations of charismatic power.

\section{Avoiding cultural determinism}

As the previous section has shown, we must resist the reification of biological categories that Weber's discussions of charisma intermittently encourage by pointing to the fact that these are, instead, cultures of masculinity. It is important, however, to be wary of how the inverse commitment - one that would supplant a biological determinism with a cultural one - also threatens to render an overly-traditionalized form of charisma that would obscure another Weberian notion that is (this time) worth preserving: namely, the revolutionary, antinomian quality of the charismatic challenges as Weber described them. That is, the constitutive elements of "shared culture"-repertoires, expectations, values, a sense of precedent-are in themselves insufficient for capturing the ways in which charisma draws on the idiosyncrasies of "the personal" as a means of disrupting enculturated expectations.

The first way Weber describes such "personal" disruptions as taking place involves the eccentricities of individual affect. The frequency with which Weber turns to the "berserk" and the "epileptoid," as examples throughout his writings, and the stress that he puts on "suffering" and "mortification" as sites for charismatic attribution in The Social Psychology of The World Religions (1946a; see also 1958, p. 219) suggest that he viewed charisma as originally arising from within the granularity of the micro-interactional range at which individual (even random) personal variability and eccentricity can be consequential for power relations. For Weber, "personal traits" are thus a wellspring for agentic disruptions of the social order not because (as others have misunderstood) he subscribed to the notion that psychological or physical idiosyncrasies are in themselves a source of "magnetism." (Such thinking would be as foreign to Weber as the anagogic idea that epilepsy truly puts one in

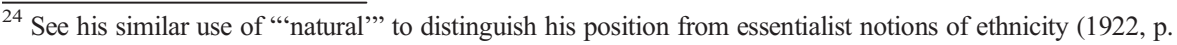
386).
} 
touch with spirits or that birthmarks are holy inscriptions upon the skin). Rather, Weber stresses the importance of individual-level eccentricity because it is a social medium that becomes propitious for attributing the sense that one is "marked-out" - this is the oddnesscum-extraordinariness that frequently serves as a precondition for charismatic acclamation (see, in particular, 1946a, pp. 270-274, 287).

The second element of charismatic disruption stressed by Weber is cultural antinomianism more generally. That is, what distinguishes charisma from the other forms of authority is its radical alterity - its capacity to startle, to shock, and to defy expectations about "what leaders do." Weber could not be clearer on this point: the charismatic leader "transforms all values and breaks all traditional and rational norms" (1922a, p. 246), and charismatic dictates represent "the most extreme contrast to formal and traditional prescription" (ibid., pp. 1115). In their introduction to the first English translations of Weber, Gerth, and Mills (1946, p. 52) refer to charisma as a form of "baffling success" within society - this, because charismatic leaders, buoyed by the charismatic mission, break rules and cultural scripts as a matter of course. The charismatic leader is thus not best characterized as someone who occupies the top position within a widely-recognized scale of value (as the traditional masculine hegemon would be). Rather, she is an insurgent who comes in, as it were, "out of left field," overturning value-tables, as "the great revolutionary force" against tradition (Weber 1922a, p. 245, emphasis original).

One can see how both factors mentioned above-personal eccentricity and cultural antinomianism - can serve as the basis for the fundamental charismatic requirement that a leader be viewed as spezifisch außertäglichen or, "specifically outside the everyday""set apart" from the expectations and protocols that guide all other (non-charismatic) individuals (Weber 1922b [1956], p. 140; also Weber 1922a, pp. 241, 1111, 1115). There is thus a danger inherent in the Bourdieusian reading that would style charisma as a form of "religious capital" (Bourdieu 1991; Rey 2007), and Bourdieu is mistaken when, in an effort to move beyond essentialism or leader-centrism, he asserts that "the religious or political prophet always preaches to the converted" (Bourdieu and Passeron 1970[1977], p. 25). Weber contrasts the charismatic prophet with the traditionalist priest precisely because he wants to distinguish those who present themselves as the models of religious orthodoxy (i.e., priests) from the provocative entrepreneurialism of those who would challenge them (i.e., prophets [1922a, pp. 439-442]), and in three places he uses the famous anaphora "it is written ... but I say unto you ...!" to emphasize the antinomian impulse behind charismatic challenges (1922a, pp. 243, 987; 1946a, p. 296). Thus, to the extent that one is absolutist about "culturalist" readings of charisma, one risks robbing it of its potential for radical challenge; a reduction of charisma — once again — to a custombound, traditional mode of authority.

Those more sensitive to the specifically exceptional nature of charismatic agency therefore tend to resist Bourdieu's interpretation of Weber's charisma as something that is completely circumscribed by culture. In Verter's view, for example, Bourdieu "retains the term [charisma], but only in Weber's sense of "the charisma of office"" (2003, p. 153, note 7). Bryan Turner (2011, p. 233) similarly writes that Bourdieu's reading " $\mathrm{rob}[\mathrm{s}]$ charisma of its transformative agency by ... making it look more like traditional authority, that is, a form of authority that is compatible with existing dispositions." In Turner's view, this interpretation is "in fact completely misplaced and misleading" (ibid.). Smith (2013, p. 58, note 90) points out that Bourdieu's 
approach "plainly ... negate[s] the rupture with 'a pre-existing signified' which is the crux of the charismatic phenomenon" that Weber so deliberately described.

Support for a non-Bourdieusian reading is also to be found in the empirical literature. In an analysis of a number of new religious movements, Dawson (2002) described various interventions that charismatic leaders will often stage in order to disrupt the expectational field that develops around them, as a means of vitiating processes of routinization. These interventions include, (a) making sudden and radical shifts within a group's doctrinal culture, (b) escalating demands placed on followers, (c) engaging in crisis-mongering to increase social solidarity, and (d) disrupting social networks by changing the physical location of a charismatic community (2002, pp. 92-94). All of these actions are suggestive of situations in which the personal agency of the leader takes precedence over enculturated expectations from followers and pre-existing repertoires for leadership and followership alike.

Thus, we can see that if one were to place too much weight on the "expectational ecology" in which charisma manifests (Zhe 2008), one would become impercipient of the agentic, "eventful" pattern-disruptions (Wagner-Pacifici 2017) that are the substance and proof of charismatic legitimacy; disruptions that, contra Bourdieu, constitue preachings that work in opposition to what "the converted" have come to expect. Thus, if it is true that charisma is shaped by tradition, then this is as much in the negative sense (with charisma serving as the antithetical principle that dialectically challenges commonly-shared or traditional expectations) as it is in the positive sense (with charisma following pre-established cultural scripts as a means of demonstrating power). ${ }^{25}$

Once again, Weber's examples are instructive on this point, but in a way that he apparently did not intend. Take the aforementioned "men's house" or the "Bull of Apis" (1922a, pp. 249-250, 247). As already described, Weber can be faulted here for an uncritical masculinist naturalism with respect these examples. One can also see, however, that he is uncritical in another sense; namely in that these examples surely represent only highlyritualized, institutionalized (and therewith diminished) shadows of the original charismatic force that would have given rise to these traditions in the first place. One can imagine, for example, how a radical insouciance to these traditional masculine honorifics, expressed

\footnotetext{
${ }^{25}$ In Bourdieu's broader corpus, his concept of habitus denotes an "embodiment" that seeks to explain how our basic habits and personal practices cohere as a "system of structured, structuring dispositions" (1980, p. 52). As such, one might seek to draw from a Bourdieusian approach to theorize the biological, psychological, and antinomian factors described in this article and indicated by Weber; accounting for the radically divergent aspects of charismatic expression while still explaining its rise in a historically contingent way (see Bourdieu 1977, 1980, 1998; Bourdieu and Wacquant 1992). We find Bourdieu's take on charisma to be irreconcilable with Weber's vision, however. Where Weber makes room in his theory for agency in the most individual and arbitrary sense, Bourdieu contends that charisma is always moored to some content-laden a structural foundation - it is "structure all the way down." We will put aside grand questions about whether Bourdieu's attempt to overcome structure-agency dualism invites participation in tautology and infinite regress (but see Alexander 1995, pp. 136-149). Instead, and more specifically, in light of Weber's account of charismatic processes and in light of our own empirical research into charismatic phenomena (Joosse 2006; 2007; 2014; 2017; 2018a; 2018b; 2019), we simply agree with others (Smith 2013; Turner 2011; Verter 2003) that the Bourdieusian approach inclines one to be impercipient of precisely what Weber was after in his descriptions of charisma; namely to sketch the actual limits of structure as an explanans for social process. For Weber, charisma is dynamite - a form of anti-structure, rather than a form of opposing structure or a feature of the endless possibilities that inhere structural hybridity. While making ample room in his theory for structural causation (via the rational-legal and traditional forms), Weber seems to know and acknowledge what Bourdieu seems to be constitutionally unable to see: that social life contains stubborn individuals who are always capable of surprising us and whose actions cannot always be explained by way of cultural-structural lineageeven as they go on to have cultural-structural effects.
} 
through audacious or impertinent acts of desecration (the non-binary gender expressions of Pharaoh Akhenaten come to mind here) could in themselves be charismatically affective catalysts within the charged atmosphere where such traditional rituals take place.

\section{Theorizing gender and charisma in the time of Trump}

But to demonstrate charisma's continued relevance, it is necessary to look beyond both the social-historical context that gave shape to Weber's thinking and the historical cases that he used for inspiration. Fortunately, the present moment offers an ideal opportunity to examine confluences and departures between charismatic and gendered power. It has now become a matter of scholarly consensus, for example, to say that Trump is "charismatic" to those who support him (Hochschild 2016; Joosse 2018a, 2018b; Lukes 2017; Mast 2016; Meyer 2016; Wagner-Pacifici and Tavory 2017; Zaretsky 2019). Indeed, Steven Lukes (2017, p. 1) assessed Trump's first year as President and noted that his "exercising of presidential power approximated Weber's ideal-typical picture of how charisma works ... remarkably closely." 26

At the same time, masculine "toughness" featured heavily in the persona that Trump advanced during his charismatic rise. Graduated scales of masculinity frequently served as a staging ground for 'vectors of ascendency' that Trump would use to vault himself over opponents during the 2015-2016 campaign. Take his attack on "little Marco" Rubio during a 2016 campaign rally:

Marco Rubio, who stood with me [at a previous debate], he was with me when he had the meltdown, and I'm telling you it wasn't a pretty sight [crowd laughter] ... he was soaking wet, I'm telling you. He was wet, boy I said, "What the hell is going on over here?" I thought he just came out of a swimming pool, he was soaking. I said "Wow, [are] you OK?" Now when we get in with Putin, we need people that don't sweat, let me tell you [loud cheering]. Gotta have people who don't sweat. Can you imagine Putin sitting there waiting for the meeting and this guy walks in and he's like a wreck? Nah. [raising his voice] You gotta have Trump walk into that meeting folks! [loud cheering] We're gonna do very nicely. (February 15, 2016, South Carolina rally).

In this and many other instances that need not be rehearsed here, ${ }^{27}$ Trump thus effected a machismo that gained its performative bearing amid contests against both "unworthy

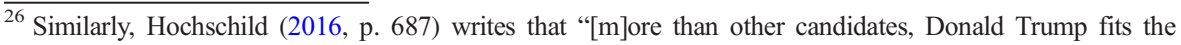
classic description of a charismatic leader, as Weber defined it."

${ }^{27}$ It would be beyond the limits of the format to provide many examples, but to add just one more, such "toughness" was also a feature of Trump's "take-down" of establishment candidate Jeb Bush (from the GOP debate on December 15, 2015):
}

Look, look, look. We need a toughness. We need strength.... And if we don't get it back fast, we're just going to go weaker, weaker and just disintegrate.... Jeb comes out and he talks about the [US's southern] border, and I saw it and I was witness to it, and so was everyone else, and I was standing there, [quoting Bush] "they come across as an act of love"- he's saying the same thing right now with radical Islam. And we can't have that in our country. It just won't work. We need strength. 
challengers" (in this case, Rubio) and "colossal players" (here, Putin) on the world stage (Joosse, 2018a, pp. 929-937). We know this mis-en-scène all too well. It is a dramaturgy that relegates women to the backdrop as "conquests" or "trophies"objects whose value can only be fully realized within the logic of the beauty pageant, ${ }^{28}$ or (in less settled times) as the spoils of war (Card 1996; Diken and Lausten 2005). In this setting, ramboid criminal sexuality, far from being a disqualifier, cashes out as masculine currency.

Clearly, then, it would be possible to explain the appeal of Trump with reference to the warrior-like examples Weber frequently employed in his descriptions of charisma. Dispossessed of the capacity for subjective volition, women are programmatically excluded from this putatively charismatic leadership style. Furthermore, it would be possible to assert that Trump's success was predicated on establishing a synergistic concordance between his boorish affect and pre-existing sentiment pools of misogyny within the electorate. In such a view, Trump was successful (and therewith, "charismatic") because he explicitly, if startlingly, articulated erstwhile hidden transcripts of sexism, for which his audience was primed and "charisma hungry" (Scott 1990, pp. 221-227; Tucker 1968, p. 745). This is the Bourdieusian "correspondence theory" that would allow us to say that Trump was preaching to the converted all along (Bourdieu and Passeron 1970[1977], p. 25).

Without denying the importance of misogyny to Trump's overall appeal (Bock et al. 2017; Setzler and Yanus 2018), we assert that an exclusive reliance on this analytic tack would obscure what, specifically, made Trump charismatic - subjecting charismatic "exceptionality" to an eliminative process that threatens reduction to its zero-point. Rather than correspondence, it should be clear by now that we are proposing a charisma that, following Weber, finds itself first and always in discord with tradition (1922a, b, pp. 243246, 439-442, 987, 1115; 1946a, p. 296). This charisma subsists not through attachments to existing cultural structures (sexist or otherwise), but rather by way of breakages with them. This charisma actively refuses the systematicity that would be implied and required for the project of assembling sets of warrior-like qualities that, taken together, could be said to comprise charisma's essence. We have already used a colloquialism to say that charisma comes "out of left field" - a phrase that never actually intends to indicate a literal "lefward" point of origin. Similarly, the charisma we propose is not locatable with positive cultural-structural coordinates in the way that traditional scripts for masculine dominance are. In short, the "pure" charisma that Weber sought to describe (and always, necessarily, failed to illustrate) cannot be rendered as a type of predictable content. It only can be described as a de-essentialized, processual form; as the brand of personal acumen that becomes available and attributable in the midst of obstinate interruptions of tradition, or via irrational ripostes to "reasonable" or principled expectations for conduct. This is the "purity" of Weber's charisma as it exists before its entry into the world of social pattern (Weber 1922a, pp. 246, 1121; see also Jameson 1973). Only later, after this inceptive moment, will this charisma concretize into more structured, routinized, lesser forms (Weber 1922a, pp. 1121-1148).

\footnotetext{
${ }^{28}$ Between 1996 and 2015, Trump was the owner of the Miss Universe Organization. In September, 2015, Trump commented on GOP rival Carly Fiorina: "Look at that face! ... Would anyone vote for that? Can you imagine that, the face of our next President?! ... I mean, she's a woman, and I'm not s'posedta say bad things, but really, folks, come on. Are we serious?" (quoted in Solotaroff 2015).
} 
So how can we affirm Trump's masculinist performances as being important to his charismatic affect, while also rejecting an essentialist approach that would link such warrior-like masculinity to charismatic authority in a deeply necessitarian or ontological sense? The first step would be to acknowledge that, for all that Trump may have embodied familiar hegemonic qualities, he did so in a way that was itself strangely burlesque, involving a surfeit of performance, a superabundance of affect that tended to push caricature past the point where it transmogrifies into qualitative difference. Trump's unrelenting and gratuitous sexist commentary is well known. Rather than engaging in a repeat airing here, ${ }^{29}$ more insight into this sexism's performative impact can be gleaned if we calibrate it within the context of the "Trump phenomenon" itselfseeing it as Trumpspeak qua Trumpspeak. This comparative heuristic has the advantage of allowing for a way in to the analysis of form.

For example, consider the sexist comments alongside Trump's disparaging remarks about John McCain, who Trump claimed was "not a war hero" because he was caught (Luntz 2015). Or the comment that, although he is a professed Christian, he has never felt the need to ask God for forgiveness (ibid.). Or consider his repeated attacks on "gold star families" (family members of those who have died in US military service). Or his early and frequent expressions of admiration for Vladimir Putin as a "strong leader" (e.g., GOP debate, 10 March 2016). Or his public call for Russia to "find" 30,000 of Hillary Clinton's emails, which were obtained as part of a hack and released by Wikileaks (Trump 2016). Or his mocking of a journalist with a physical disability (campaign rally, November 24, 2015). Or his continual promulgation of the notion that, if he were to lose, this would demonstrate a "rigging" of the American electoral system (multiple dates). Then there are the outlandish claims of personal ability: "There's nobody bigger or better at the military than I am" (quoted in Wilstein 2015). "Nobody reads the Bible more than me" (Woolf 2016). "I know words.... I have the best words" (campaign rally, December 30, 2015). "I will be the greatest jobs President God ever created" (Trump 2015). And most perversely, considering our topic: "Nobody has more respect for women than Donald Trump!" (Trump 2016).

Statements like these can only be regarded as issuing from someone who is actively unserious; either in the sense that they are being said in jest ${ }^{30}$ (and cheering laughter would invariably ensue), or "not taking things seriously" in the sense of harboring an insouciant disregard for all of the normative strictures that usually bear down upon candidates for office. Trump consistently flouted protocols for electoral culture (pertaining to credibility, proportion, consistency, modesty, couth, etc.), that would ordinarily punish or reward aspiring candidates. Moreover, when assessed in aggregate, it becomes clear that Trump's performances proceeded without reference to the customary landmarks that normally give shape to the American political landscape. For example, Trumpspeak simply failed to hew to, and was incommensurate with, left/right distinctions that typically cleave the American political sphere, and in many cases his words and actions were as likely to rankle traditional Republican voters as Democrats (Joosse 2018b, pp. 1006-1007). ${ }^{31}$ Instead of political loyalty or moral-cultural piety,

\footnotetext{
${ }^{29}$ But for a good selection, see Darweesh and Abdulla (2016).

${ }^{30}$ Trump would later say he was joking about the request for Russia to "find" the Clinton emails, for example.

${ }^{31}$ The statements about McCain fall into this category, as does, for that matter, the vulgarity of his comments about women.
} 
with Trump one felt that earnest opinion was being supplanted by a more basic perlocutionary aim: to shock, to disturb, to regale — but most basically, to defy scripts relating to how incipient Presidents should act. Thus, rather than bringing us onto the familiar territory where traditional morality intersects with and upholds power, Trump's hyperbolic ${ }^{32}$ and politically-disingenuous aggression tended to effect a sense of departure from the normal, into uncharted moral territory; even into the surreal (Goldstein and Hall 2017). In short, when Trump appeared in American electoral culture, it was unmistakable that he was appearing as a different kind of beast.

Other scholars have similarly begun to prioritize performative affect over ideological and moral content in their accounts of Trump's power. For instance, Wagner-Pacifici and Tavory link Trump's interruptive capacity to his charisma in their essay, "Politics as a Vacation," maintaining that for many voters, Trump represented "a rupture in the predictable trajectories of political life," in which "[b]eing thrown into the unknown was a compelling, seductive, and energizing prospect" (2017, pp. 307-308). One supporter they quote made an astonishing disclosure about the extent to which rupture - rather than moral adhesion - functioned as a sort of prime mover behind his support:

A dark side of me wants to see what happens if Trump is in.... There is going to be some kind of change, and even if it's like a Nazi-type change, people are so drama-filled. They want to see stuff like that happen (Victor Vizcarra, quoted in Wagner-Pacifici and Tavory 2017, p. 311).

Without discussing charisma per se, Hahl et al. (2018) use the Trump example as a means of demonstrating how flagrant violations of established norms can lead to what they call the "authentic appeal of the lying demagogue." The elliptical avoidance of content in this formulation is striking: followers attribute to leaders a brand of "authenticity" that obtains, seemingly paradoxically, by way of an appreciation of that leader's complete unconcern with making truthful statements. Judith Butler, who could not actually bring herself to describe Trump as "charismatic," nevertheless recognized an important McLuhanian distinction between the loutish content of Trump's persona and the cultural centrality that such loutishness enabled him to achieve: ${ }^{33}$

Many of us took his arrogance, his ridiculous self-importance, his racism, his misogyny, and his unpaid taxes to be self-defeating characteristics, but all of those were frankly thrilling for many who voted for him.... So even though [Trump] is not charismatic in any traditional sense, ${ }^{34}$ he gains size and personal power through taking up the screen in the way that he does. In this sense, he

\footnotetext{
${ }_{32}$ Trump called this "truthful hyperbole" and described it as "an innocent form of exaggeration — and a very effective form of promotion" (Trump and Schwartz 1987, p. 40).

${ }^{33}$ Trump's controversial media performances netted him an estimated \$2B in publicity prior to March 2016. This was nearly twice the total budgets of Obama and Romney's 2012 presidential campaigns (Confessore and Yourish 2016).

${ }^{34}$ Note that the notion that one could be "charismatic in [a] traditional sense" is a contradiction in terms that Weber's tripartite typology is expressly designed to avoid. Butler thus doesn't recognize Trump as being charismatic, but at the same time goes on to describe several features that conform to the ideal type, as per Weber's descriptions.
} 
allows for an identification with someone who breaks the rules, does what he wants, makes money, gets sex when and where he wants it. (emphases added).

This commentary, of diverse social-theoretical provenance, circles in and coalesces around a shared point: it is not traditional moral-ideological content per se that was most germane to Trump's distinctive appeal, but rather the use of such content to effect an insurgent, anti-structural campaign that was - by virtue of its anti-structural naturethrilling to his constituency. In Michael Moore's rather more terse assessment, Trump supporters saw him "as the human Molotov cocktail they get to throw into the system" (Wang 2016). ${ }^{35}$ Whatever "correspondence" or "resonance" Trump found in these circumstances thus owes not to his adherence to particular moral-cultural traditions (again, sexist or otherwise) that were emblematic of pre-existing cultural-structural power. Rather, Trump's appeal stemmed from his active hostility toward structure itself. This hostility is precisely the dynamic that Weber was describing a century ago when he positioned charisma as an antipode to both tradition and bureaucracy in his enormously influential tripartite division of legitimate authority.

That charisma is at stake in such instances, however-and that Weber provides the social-theoretical key here-is not demonstrated by the mere presence of anti-structural volleys. Rather, the charismatic sheen of Trump revealed itself through the positive affectual qualities - "supernatural, superhuman, or at least specifically exceptional powers" (1922a, b, p. 241) - that he was able to acquire amid his battles with structure. One final example will illustrate how anti-structural affect links closely with miraculous legitimation in this way. During the first GOP candidates' debate, Fox News moderator Megyn Kelly began the first question to Trump by confronting him with his long history of referring to women as "fat pigs, dogs, slobs, and disgusting animals...." In the middle of this expatiation of his misogyny, Trump raised a single finger and cut in: "Only [to] Rosie O'Donnell." The crisp response - an obvious falsehood - elicited rapturous laughter and applause alongside howls of disapproval. Undoubtedly, Trump both won and lost some support based on appreciation or disgust (as it may be) with this doubling down on sexism. Prevailing over and above this, however, was a recognition of the charismatic accomplishment itself: this was an undeniable triumph for Trump's performative abilities. He had defused the criticism with humor, defied the logic of Presidential disqualification that was clearly in operation, and escaped from what, for any other candidate, would have been a deadly snare (Joosse 2018a, pp. 931-932; Mast 2016).

It was a trick that Trump would repeat again and again throughout the campaign, building iteration upon iteration into a recursive pattern of what Isaac Reed (2013, p. 255) has called self-referential, self-justifying "spiral[s] of success." When structural power sought to reassert its institutional strength via the "never Trump" movement, this only provided the basis for a greater, more devastatingly impressive achievement: the refurbishment of the GOP — from the grassroots and up through its most senior ranksinto the "Trump party."

\footnotetext{
$\overline{35}$ This is probably the only viewpoint that Moore would share with, say, Rush Limbaugh (2016), who early on noted: "Everything he's doing goes against the book.... Everything that any analyst or consultant or professional would tell you not to do, Donald Trump is doing it, and he's leading the pack [of GOP candidates]. This creates its own set of emotions and feelings and thoughts that run from person to person" (emphasis added).
} 
Although this process was something that of course brought joy to those who supported him, it also had the odd effect of compelling commentators and even critics to start crediting him with miraculous powers. Trump had become "Teflon Don" (Illing 2016), the candidate who could make impossibly outrageous statements that "would have ended the career of any ordinary politician" (Robinson 2015). He was someone who, as multiple commenters noted, "def[ied] the modern laws of political gravity" (Cooper 2015; see also Castellanos 2018; Luntz 2016). ${ }^{36}$

And so, amid descriptions of Trump's impossible accomplishments, the language of miracles - so central to Weber's account of charismatic legitimation - emerged and gained currency in the American civil sphere. One could object that such expressions were idiomatic rather than charismatic. Nobody truly believed that Trump was endowed with some magical power that rendered him invincible and his ascent inevitable. But this was never a criterion for Weber, who made room for charisma's appearance, even in disenchanted modernity, by way of his gloss from the "supernatural, superhuman" qualities so often found in religious settings, to the "specifically exceptional" powers that were more characteristic of his contemporary political examples (1922a, p. 241; Joosse 2014). What is most important, from a performative perspective, is that these commentators were reaching for the highest superlatives they could muster, all the while throwing up their hands in disbelief as their conventional political wisdom failed them. These self-styled experts, in many cases no friends of Trump, were used to being credited with the ability to "read the horses." Insofar as Trump was contravening taken-for-granted social laws during his ascent within American politics, then, he was giving expression to charisma in a state of sociological purity. This was the miracle of social levitation.

We will end with two takeaway points related to the analysis of charisma that that we have undertaken in this article. (1) Sexist, masculinist affect is neither necessary for charisma, nor is it sufficient for it. The muscular style so often referenced by Weber and performed so cartoonishly by Trump is, in its content-related dimensions at least, more indicative of traditional power. This first point is important because it may offer clues as to the trajectory of decline that Trump's charisma will eventually take. Because the logic of charisma revolves around defying expectations and being impressively "shocking," Trump's performances, to the extent that they become predictable, may ultimately prove to be charismatically self-limiting. Political systems across the world have by turns been roiled by charismatic candidates who elicit shock and awe with their chestpuffery, their "womanizing," and their sexual "indiscretions" (euphemisms that often conceal outright criminality). But to the extent that we are able to look beyond our own political borders and recognize Trump as a social type that conforms to a social trend (running from Silvio Berlusconi and Toronto Mayor Rob Ford as predecessors, through Trump and to Boris Johnson and Jair Bolsonaro, as successors), later examples who shuffle by in this procession may begin to be viewed as old-hat, boring, and corny - or as calculating counterfeiters. In short, as political subjects, we may begin to put aside charismatic "recognition" and start to regard such characters as contributors to a

\footnotetext{
${ }^{36}$ Castellanos (2018) pursued this theme in most detail: "Washington is debating a different set of laws these days: The laws of physics. Do Newton's principles affect Donald Trump like other inhabitants of our planet? There is evidence Trump has the power to defy gravity: When this president slips, he doesn't fall, he floats. It is frustrating the establishment to no end." Sociologist Todd Gitlin similarly wrote that "[h]is power is such that he is not subject to laws of ordinary grammar" (Gitlin 2017).
} 
leadership tradition that - as a tradition — can only ever become less charismatically exciting (Weber 1922a, p. 242). Earlier this year, Trump courted controversy once again by launching sexist and racist attacks on four congresswomen (Ayanna Pressley, Ilhan Omar, Alexandria Ocasio-Cortez, and Rashida Tlaib), telling them to "go back" to countries from which they came (all but Omar were actually born in the United States). It seems to us that Pressley's response, given in a press conference after the remarks, was the right one: "We should not take the bait. We can sit here and continue to recycle his hateful rhetoric of which I cannot feign surprise or inflated outrage because he is, if nothing else, predictable" (quoted in Durkee 2019). ${ }^{37}$ Recycled rhetoric, predictable outrage, feigned surprise - this is anti-charisma at work.

(2) As a leadership style, charisma is certainly available to those who would look very different from traditional masculine warriors. Weber's blindness to the charismatic potential inherent in challenges to regularized gender scripts helps us to improve on his vision (Bologh 1990, p. xv), giving a better justification for some of his own inclusions in the category that, on their face, seem to cut against the warrior-like descriptions that are predominant in his writing ("gentle Jesus, meek and mild" being the most conspicuous example). ${ }^{38}$ It can also help to explain some notable omissions from his work. How can it be, for example, that Joan of Arc - a charismatic heroine if there ever was one-is absent in Weber's discussions? Suffering from epileptic visions that became the basis for charismatic ideation by herself and her followers, Joan's remarkable successes "in a man's world" were crucial for her charismatic legitimation. According to Marina Warner, Joan "transgressed against class, sex, social boundaries and feudal expectations: the transgression lent her charisma, and earned her immense influence for a while" (1996, p. 26; also Collins 2017a). Similar dynamics legitimated the earlier religious figure, Hildegard of Bingen (lived 1098-1179) who, according to Barbara Finlay's (2002) analysis, increased her charismatic recognition through remarkable public debates and challenges with increasingly powerful figures from the maledominated Roman Catholic bureaucracy, including her bishop, archbishop, and eventually even Pope Eugenius III. New religious movement scholarship points to even more fantastical possibilities resulting from denaturing interventions within traditional gender scripts. See, for example, the "reverse gender polarities" described in Palmer's (1993, 1994) accounts of the Brahma Kumaris and Rajneeshees, or how members of Heaven's Gate members sought to remove gender inscriptions on the body in their entirety (Raine 2005). Thus, while gender is often theorized as an accomplishment of routine actions that are embedded in everyday life (West and Zimmerman 1987), the transformative crucible of charismatic social relations, which operate "outside the everyday," may provide opportunities for expressing more "unruly" gender-based challenges to the social order.

If there is one point from the analysis above that may prove to have relevance during this year, it is that, to the extent that it is "pure," charisma is unlikely to be something that is successfully contrived from within the heart of the political establishment. There is some historical evidence that charismatic leaders like Trump can have the effect of provoking their own, counter-posed charismatic rivals (Reed 2013, p. 260; also Joosse

\footnotetext{
${ }^{37}$ For the press conference, see: https://www.youtube.com/watch?v=RbmUcSqFZyc

${ }^{38}$ Indeed, it seems that part of the shock of Jesus's ministry was his refusal to take up the mantel of a warriorking that would have comprised ancient Judaic expectations for a "Messiah."
} 
2018a; Smith 2000, p.104). As such, in addition to heeding lessons from political newcomers like Pressley on methods for vitiating the charismatic appeal of enemies (described above), processes of election - in the Democratic primaries and elsewhereshould involve recognizing where the charismatic energy may lie and putting more faith in following it. If Trump is to be defeated, then it seems that it will not be by an overtly "establishment candidate," who may only prove to be a structural foil that serves to reinvigorate Trump's charismatic support. Rather, the person who bests Trump will most likely be someone who can, on their own account, cause shifts in the emotional-energetic economy (Collins 2017b) that are truly challenging for Trump. One does not need recourse to Hegelian dialectics to see that recent developments (the Women's March, the \#MeToo movement, and the opposition to the Kavanaugh Supreme Court confirmation, for example) indicate a certain promise in what has been called “The Revolutionary Power of Women's Anger” (Traister 2018). But this energy, powerful though it may be in mass movement form, has yet to coalesce around a singular charismatic competitor for Trump. We should not foreclose this possibility by being unwilling to recognize it when it happens.

Acknowledgements This research was funded by a grant from the Hong Kong Research Grants Council entitled, Reimagining Charisma: From Classical Origins to Contemporary Applications (project code: 27610618). The first author would like to thank Ann Mische, John R. Hall, Gary Hamilton, Randall Collins, Seth Abrutyn, Thomas Kemple, Jo Reger, Michael Rosenberg, Joshua Derman, Cheris Shun-ching Chan, Travis Kong, Julian Groves, Xiaoli Tian, and Liping Wang for generous comments and discussions relating to this work. Both authors thank the Editors and reviewers of Theory and Society for helpful comments and direction with an earlier version of this article.

\section{References}

Abel, T. (1937). The pattern of a successful political movement. American Sociological Review, 2(3), 347352.

Abrutyn, S., \& Van Ness, J. (2015). The role of Agency in Sociocultural Evolution: Institutional entrepreneurship as a force of structural and cultural change. Thesis Eleven, 127(1), 52-77.

Agadjanian, V. (2015). Women's religious authority in a sub-Saharan setting: Dialectics of empowerment and dependency. Gender \& Society, 29(6), 982-1008.

Alexander, J. C. (1995). Fin de siècle social theory: Relativism, reduction, and the problem of reason. London: Verso.

Alexander, J. C. (2010). The performance of politics: Obama's victory and the democratic struggle for power. Oxford: Oxford University Press.

Alexander, J. C. (2011). Performance and power. Cambridge, UK: Polity.

Anthias, F., \& Yuval-Davis, N. (1983). Contextualizing feminism: Gender, ethnic and class divisions. Feminist Review, 15, 62-75.

Avishai, O., \& Irby, C. A. (2017). Bifurcated conversations in sociological studies of religion and gender. Gender \& Society, 31(5), 647-676.

Baehr, P. (2008). Caesarism, Charisma, and fate. New Brunswick and London: Transaction.

Baker, A. (1982). The problem of authority in radical movement groups: A case study of lesbian-feminist organization. The Journal of Applied Behavioral Science, 18(3), 323-341.

Beck-Gernsheim, E. (2002). Reinventing the family: In search of new lifestyles. Cambridge: Polity.

Bendix, R. (1960). Max Weber: An intellectual portrait. New York: Doubleday and Company.

Berger, P. L. (1996). Secularism in retreat. The National Interest, 46, 3-12.

Bock, J., Byrd-Craven, J., \& Burkley, M. (2017). The role of sexism in voting in the 2016 presidential election. Personality and Individual Differences, 119, 189-193. 
Bologh, R. W. (1990). Love or Greatness: Max Weber and masculine thinking - a feminist inquiry. London: Unwin Hyman.

Bourdieu, P. (1977). Outline of a theory of practice. Cambridge: Cambridge University Press.

Bourdieu, P. (1980). The logic of practice. Stanford: Stanford University Press.

Bourdieu, P. (1984). Distinction: A social critique of the Judgement of taste. Cambridge: Harvard University Press.

Bourdieu, P. (1987). Legitimation and structured interests in Weber's sociology of religion. In S. Lash \& S. Whimster (Eds.), Max Weber, rationality and modernity (pp. 119-136). London: Allen \& Unwin.

Bourdieu, P. (1991). Genesis and structure of the religious field. Comparative Social Research, 13, 1-44.

Bourdieu, P. (1998). Practical reason. Stanford: Stanford University Press.

Bourdieu, P., \& Passeron, J.-C. (1977). Reproduction in education, culture and society, translated by Richard Nice. London: Sage.

Bourdieu, P., \& Wacquant, L. (1992). An invitation to reflexive sociology. Chicago: University of Chicago Press.

Butler, J. (1990). Gender trouble: Feminist theory, and psychoanalytic discourse. New York and London: Routledge.

Card, C. (1996). Rape as a weapon of war. Hypatia, 11(4), 5-18.

Castellanos, Alex. 2018. How Trump has managed to defy gravity. Real Clear Politics. Available at: https://www.realclearpolitics.com/articles/2018/07/31/how_trump_has_managed_to_defy_ gravity_137665.html?mod=article_inline.

Chong, Kelly. (2008). Deliverance and submission: Evangelical women and the negotiation of patriarchy in South Korea. Harvard east Asian monograph 309. Harvard University Asia Center.

Cohen, C. J., \& Jackson, S. J. (2016). Ask a feminist: A conversation with Cathy J. Cohen on black lives matter, feminism, and contemporary activism. Signs: Journal of Women in Culture and Society, 41(4), $775-792$.

Collins, P. H. (1991). Black feminist thought. London: Routledge.

Collins, Randall. (2017a). When are women charismatic leaders? Joan of arc, Cleopatra, Madame Mao Zedong. The Sociological Eye. Available at: http://sociological-eye.blogspot.com/2017/02/when-arewomen-charismatic-leaders-joan.html.

Collins, Randall. (2017b). Micro-bases of social inequality: Emotional energy, emotional domination, and charismatic solidarity. The Sociological Eye. Available at https://www.drrandallcollins.com/sociologicaleye/2017/08/micro-bases-of-social-inequality.html.

Confessore, Nicholas, and Karen Yourish. (2016). \$2 billion worth of Media for Donald Trump. New York Times, march 15.

Connell, R. (1987). Gender and power: Society, the person, and sexual politics. Stanford: Stanford University Press.

Connell, R., \& Messerschmidt, J. W. (2005). Hegemonic masculinity: Rethinking the concept. Gender \& Society, 19(6), 829-859.

Connell, R. (2007a). Southern theory: The global dynamics of knowledge in social science. Crows Nest, New South Wales: Allen \& Unwin.

Connell, R. (2007b). Why is classical theory classical? American Journal of Sociology, 102(6), 1511-1557.

Cooper, A. (2015). [Trump] defies the laws of political gravity. Appearance on Latenight with Seth Myers, August 11, 2015.

Coser, L. (1981). The uses of the sociological classics. In B. Rhea (Ed.), The future of the sociological classics (pp. 170-182). Boston: Allen \& Unwin.

Crenshaw, K. (1991). Mapping the margins: Intersectionality, identity politics, and violence against women of color. Stanford Law Review, 1241-1299.

Darweesh, A. D., \& Abdullah, N. M. (2016). A critical discourse analysis of Donald Trump's sexist ideology. Journal of Education and Practice, 7(30), 87-95.

Dawson, L. L. (2002). Crises in Charismatic Legitimacy and Violent Behavior in New Religious Movements. In D. G. Bromley \& J. G. Melton (Eds.), Cults, Religion and Violence (pp. 80-101). Cambridge: Cambridge University Press.

de Beauvoir, Simone. (1949[1972]). The Second Sex. (1949[1972]). Translated by HM Parshley. Harmondsworth: Penguin.

Deay, D. (2004). "It's all becoming a habitus": Beyond the habitual use of habitus in educational research. British Journal of Sociology of Education, 25(4), 431-444.

Derman, J. (2012). Max Weber in politics and social thought: From Charisma to canonization. Cambridge: Cambridge University Press.

Devarachetty, S. (2012). Women as charismatic leaders. Ph.D: Dissertation, University of Akron. 
Diken, B., \& Laustsen, C. B. (2005). Becoming abject: Rape as a weapon of war. Body \& Society, 11(1), 1111128 .

Durkee, Alison. (2019). "We should not take the bait": AOC and the squad denounce Trump's "hateful rhetoric" as a "Distraction." Vanity Fair, July 16.

Eatwell, R. (2002). The rebirth of charisma? Concepts and theories and the problem of operationalisation. Colloque Cer, vol., 1.

Emmet, D. (1958). Function, purpose and powers: Some concepts in the study of individuals and societies. London: MacMillan \& Co..

Engelbrekt, K. (2009). What Carl Schmitt picked up in Weber's seminar: A historical controversy revisited. European Legacy, 14(6), 667-684.

Falco, R. (1999). Charisma and tragedy. Theory, Culture \& Society, 16(3), 71-98.

Ferree, Myra Marx, and Carol McClurg Mueller. (2004). Feminism and the Women's movement: A global perspective. The Blackwell Companion to Social Movements, pp. 576-607.

Finlay, B. (2002). The origins of Charisma as process: A case study of Hildegard Bingen. Symbolic Interaction, 25(4), 537-554.

Foucault, M. (1990). The history of sexuality. New York: Vintage.

Gerth, H. (1940). The Nazi Party: Its leadership and composition. American Journal of Sociology, 45(4), 517541.

Gerth, Hans, C. Wright Mills. (1946[1958]). Introduction. In Max Weber, From Max Weber. New York: Oxford University Press.

Gitlin, T. (2017). Gibberish is the white house's new normal. Moyers, March 24. Available at: Gibberish Is the White House's New Normal.

Goffman, Erving. (1963[1986]). Stigma: Notes on the Management of Spoiled Identity. New York: Simon \& Schuster.

Goldstein, D. M., \& Hall, K. (2017). Postelection surrealism and nostalgic racism in the hands of Donald Trump. HAU: Journal of Ethnographic Theory, 7(1), 397-406.

Hadden, J. (1987). Toward desacralizing secularization theory. Social Forces, 65(3), 587-611.

Hahl, O., Kim, M., Zuckerman, E. W., \& Sivan. (2018). The authentic appeal of the lying demagogue: Proclaiming the deeper truth about political illegitimacy. American Sociological Review, 83(1), 1-33.

Hayes, S. (1996). The cultural contradictions of motherhood. New Haven, CT: Yale University Press.

Herdt, G. (1987). The Sambia: Ritual and gender in New Guinea. New York: Holt Rinehart \& Winston.

Hochschild, A. (2016). The ecstatic edge of politics: Sociology and Donald Trump. Contemporary Sociology, 45(6), 683-689.

Hooks, Bell. 1981. Ain't I a woman? Black women and feminism. Boston: South End.

Illing, S. (2016). Teflon Don: Rubio and Cruz's stampede of attacks won't stop the Trump Juggernaut nothing will stick to this guy. Salon, February 29.

Jameson, F. (1973). The vanishing mediator: Narrative structure in max Weber. New German Critique, 52-89.

Jermier, J. M. (1993). Introduction-Charismatic leadership: Neo-Weberian perspectives. The Leadership Quarterly, 4(3-4), 217-233.

Johnson, P. E. (2017). The art of masculine victimhood: Donald Trump's demagoguery. Women's Studies in Communication, 40(3), 229-250.

Joosse, P. (2006). Silence, Charisma and power: The case of John de Ruiter. Journal of Contemporary Religion, 21(3), 355-371.

Joosse, P. (2007). The presentation of the charismatic self in everyday life: Reflections on a Canadian new religious movement. Sociology of Religion, 73(2), 174-199.

Joosse, P. (2014). Becoming a god: Max Weber and the social construction of Charisma. Journal of Classical Sociology, 14(3), 266-283.

Joosse, P. (2017). Weber's disciples: Theorizing the charismatic aristocracy. Sociological Theory, 35(4), 334 358.

Joosse, P. (2018a). Countering Trump: Toward a theory of charismatic counter-roles. Social Forces, 97(2): 921-944. https://doi.org/10.1093/sf/soy036 .

Joosse, P. (2018b). Expanding moral panic theory to include the Agency of Charismatic Entrepreneurs. British Journal of Criminology, 58(4): 993-1012. https://doi.org/10.1093/bjc/azx047 .

Joosse, P. (2019). Narratives of rebellion. European Journal of Criminology. https://doi.org/10.1177 $/ 1477370819874426$.

Kaufmann, W. (1974). Nietzsche: Philosopher, Psychologist, Antichrist. New Jersey: Princeton University Press.

Kemple, T. (2014). Intellectual work and the Spirit of capitalism: Weber's calling. New York: Palgrave Macmillan. 
Kent, S. A. (1983). Weber, Goethe, and the Nietzschean allusion: Capturing the source of the "iron cage" metaphor. Sociology of Religion, 44(4), 297-319.

Kent, S. A. (1985). Weber, Goethe, and William Penn: Themes of marital love. Sociological Analysis, 46(3), 315-320.

Lawless, E. J. (1993). Not so different a story after all: Pentecostal women in the pulpit. In C. Wessinger (Ed.), Women's leadership in marginal religions. Champaign, IL: University of Illinois Press.

Lengermann, P., \& Niebrugge, G. (2006). The women founders: Sociology and social theory 1830-1930, a text/reader. Long Grove, IL: Waveland Press.

Lerum, K. (2004). Sexuality, power, and camaraderie in service work. Gender \& Society, 18(6), 756-776.

Limbaugh, Rush. (2016). Trump refuses to play by the rules. The Rush Limbaugh Show, January 27.

Lindholm, C. (1990). Charisma. Cambridge and Oxford: Basil Blackwell.

Lukes, Steven. (2017). The big picture: Trump's Charisma. PublicBooks.org available at: http:/www. publicbooks.org/big-picture-trumps-charisma/

Luntz, F. (2015). Interview with Donald Trump at the family leadership summit. Available at: https://www. youtube.com/watch?v=eI_Y813U8mo.

Luntz, F. (2016). Donald Trump and Bernie Sanders are breaking all the rules of politics. The Telegraph, February 1. Available at: https://www.telegraph.co.uk/news/worldnews/donald-trump/12133595/DonaldTrump-and-Bernie-Sanders-are-breaking-all-the-rules-of-politics.html.

Mast, J. L. (2016). Action in culture: Act I of the presidential primary campaign in the US, April to December, 2015. American Journal of Cultural Sociology, 4(3), 241-288.

McAdams, D. P. (2017). The appeal of the primal leader: Human evolution and Donald J Trump. Evolutionary Studies in Imaginative Culture, 1(2), 1-13.

McGuire, M. (1983). Discovering religious power. Sociological Analysis, 44(1), 1-9.

Meyer, D. (2016). Trumpism and the threat of violence. Politics outdoors. Available at: https://politicsoutdoors.com/2016/03/24/trumpismand-the-threat-of-violence/.

Milkman, R. (2017). A new political generation: Millennials and the Post-2008 wave of protest. American Sociological Review, 82(1), 1-31.

Mommsen, W., \& Steinberg, M. (1990). Max Weber and German politics, 1890-1920. Chicago: University of Chicago Press.

Morris, A. (2015). The scholar denied: WEB Du bois and the birth of modern sociology. Berkeley: University of California Press.

Moy, P., Xenos, M., \& Hess, V. (2005). Communication and citizenship: Mapping the political effects of infotainment. Mass Communication \& Society, 8(2), 111-131.

Murray, S. (1996). American gay. Chicago: University of Chicago Press.

Nietzsche, Friedrich. (1886 [1992]). Beyond good and evil. In Basic writings of Nietzsche. Trans. Walter Kaufmann. The Modern Library: New York, pp. 179-435.

Nietzsche, F. (2008). Thus Spoke Zarathustra: A Book for Everyone and Nobody. (translated by Graham Parkes). Oxford: Oxford University Press.

Olick, J. K., \& Levy, D. (1997). Collective memory and cultural constraint: Holocaust myth and rationality in German politics. American Sociological Review, 921-936.

Osselaer, V., Tine, L. R., Smeyers, K., \& Graus, A. (2020). Charismatic women in religion. Power, media, and social change. Women's History Review, 29(1), 1-17.

Palmer, S. J. (1993). Women's “cocoon work" in new religious movements: Sexual experimentation and feminine rites of passage. Journal for the Scientific Study of Religion, 32(4), 343-355.

Palmer, S. J. (1994). Moon sisters, Krishna mothers, Rajneesh lovers: Women's roles in new religions. Syracuse: Syracuse University Press.

Parsons, T. (1963). Introduction. In M. Weber (Ed.), The Sociology of Religion (pp. xxix-lxxvi). Boston: Beacon Press.

Potts, J. (2009). A history of Charisma. London: Palgrave Macmillan.

Raine, S. (2005). Reconceptualising the human body: Heaven's gate and the quest for divine transformation. Religion, 35(2), 98-117.

Reed, I. A. (2013). Charismatic performance: A study of Bacon's rebellion. American Journal of Cultural Sociology, 1(2), 254-287.

Reger, J. (2002). Organizational dynamics and construction of multiple feminist identities in the National Organization for women. Gender \& Society, 16(5), 710-727.

Reinhard, B. (1960). Max Weber: An intellectual portrait. New York: Doubleday.

Rey, T. (2007). Bourdieu on religion: Imposing faith and legitimacy. New York: Routledge.

Rieff, P. (2007). Charisma: The gift of grace and how it has been taken away from us. New York: Pantheon Books. 
Robinson, G. (2015). Trump isn't going away. Gulf News. July 21, 2015. Available at: https:/gulfnews. com/opinion/op-eds/trump-isntgoing-away-1.1553939.

Roth, G., \& Schluchter, W. (1979). Max Weber's vision of history. Berkeley: University of California Press.

Roth, G. (2001). Max Webers deutsch-englische Familiengeschichte 1800-1950: mit Briefen und Dokumenten. Tübingen: Mohr siebeck.

Schluchter, W. (1985). The rise of Western rationalism: Max Weber's developmental history. Berkeley: University of California Press.

Scott, J. C. (1990). Domination and the arts of resistance: Hidden transcripts. New Haven, CT, and London: Yale University Press.

Setzler, M., \& Yanus, A. B. (2018). Why did women vote for Donald Trump? PS: Political Science \& Politics, 51(3), 523-527.

Smith, P. (2000). Culture and charisma: Outline of a theory. Acta Sociologica, 43(2), 101-111.

Smith, D. N. (2013). Charisma disenchanted: Max Weber and his critics. Current Perspectives in Social Theory, 3, 3-74.

Solotaroff, Paul. (2015). Trump seriously: On the trail with the GOP's tough guy. Rolling Stone 9.

Tavory, I., \& Eliasoph, N. (2013). Coordinating futures: Toward a theory of anticipation. American Journal of Sociology, 118(4), 908-942.

Terry, Bandon. (2018). MLK Now. The Boston Review. Sept 10. Available at: http://bostonreview. net/forum/brandon-m-terry-mlk-now.

Thomas, J. J. R. (1985). Rationalization and the status of gender divisions. Sociology, 19(3), 409-420.

Thomas, J., \& Kukulan, A. (2004). "Why Don't I know about these women?" the integration of early women sociologists in classical theory courses. Teaching Sociology, 32(3), 252-263.

Thussu, D. (2008). News as entertainment: The rise of global infotainment. Atlanta: Sage.

Traister, R. (2018). Good and mad: The revolutionary power of women's anger. New York: Simon and Schuster.

Trump, D., \& Schwartz, T. (1987). Trump: The art of the deal. New York: Random House.

Trump, D. (2015). Campaign announcement speech. June 16.

Trump, D. (2016). News conference in Miami, Wednesday, July 27.

Tucker, R. C. (1968). The theory of charismatic leadership. Daedalus, pp. 731-756.

Turner, B. S. (2011). Pierre Bourdieu and the sociology of religion. In S. Susen \& B. S. Truner (Eds.), The legacy of Pierre Bourdieu: Critical essays (pp. 223-246). London: Anthem.

Verter, B. (2003). Spiritual capital: Theorizing religion with Bourdieu against Bourdieu. Sociological Theory, 21(2), 150-174.

Wagner-Pacifici, R. (2017). What is an event? Chicago: University of Chicago Press.

Wagner-Pacifici, R., \& Tavory, I. (2017). Politics as a vacation. American Journal of Cultural Sociology, 5(3), 307-321.

Wallis, R. (1982). The Social construction of charisma. Social Compass, 29(1), 25-39.

Wang, C. (2016). Michael Moore says Trump is a "human Molotov cocktail" supporters get to throw. CNBC, [online].

Weber, M. (1926 [1975]). Max Weber: A biography. Translated by Harry Zohn. New York: Wiley.

Weber, M. (1915 [1951]). The religion of China: Confucianism and Taoism. Translated and edited by Hans Gerth. New York: The Free Press.

Weber, M. (1916 [1958]). The Religion of India: The Sociology of Hinduism and Buddhism. Translated and edited by Hans Gerth and Don Martindale. Glencoe, IL: The Free Press.

Weber, M. (1919 [1952]). Ancient judaism. Translated and edited by Hans Gerth and Don Martindale. New York: The Free Press.

Weber, M. (1920). The Protestant Ethic and the Spirit of Capitalism. Translated in 1930 by Talcott parsons. 1958 reprint (second ed.). New York: Scribner.

Weber, M. (1922a [1978]). Economy and Society, 2 vols., Guenther Roth and Claus Wittich, eds. Berkeley: University of California.

Weber, M. (1922b [1956]). Wirtschaft und Gesellschaft. Tübingen, Germany: J.C.B. Mohr (Paul Siebeck). Berkeley: University of California Press.

Weber, M. (1946a). The social psychology of the world religions. In From Max Weber: Essays in Sociology, pp. 267-301.

Weber, M. 1946b. "Science as a Vocation," in From Max Weber: Essays in Sociology, Hans Gerth and C.W. Mills, eds., pp. 129-156. New York: Oxford University Press.

West, C., \& Zimmerman, D. H. (1987). Doing Gender. Gender \& Society, 1(2), 125-151.

Whalen, T. (2014). Engendering Charisma: k. d. Lang and the comic frame. Intertexts, 18(1), 9-28. 
Wignall, R. (2016). "A man after God's own heart": Charisma, masculinity and leadership at a charismatic Church in Brighton and Hove, UK. Religion, 46(3), 1-23.

Woolf, N. (2016). The first godless US election. The New Statesman, May 31. Available at: https:// www.newstatesman.com/politics/religion/2016/05/first-godless-us-election.

Zaretsky, E. (2019). Trump's charisma. London Review of Books, June 27. Available at: https://www.lrb.co. uk/blog/2019/june/trump-s-charisma.

Zeitlin, I. M. (2019). Classical sociological theory. Toronto: Canadian Scholars' Press.

Zelditch Jr., M. (2001). Theories of legitimacy. In J. T. Jost \& B. Major (Eds.), The psychology of legitimacy (pp. 33-53). Cambridge: Cambridge University Press.

Zhe, J. (2008). Expectation, affection and responsibility: The charismatic journey of a new Buddhist group in Taiwan. Nova Religio, 12(2), 48-68.

Publisher's note Springer Nature remains neutral with regard to jurisdictional claims in published maps and institutional affiliations.

Paul Joosse is Assistant Professor of Sociology at the University of Hong Kong. Recent articles of his include "Countering Trump: Toward a Theory of Charismatic Counter-roles" (Social Forces 2018), "Max Weber's Disciples: Theorizing the Charismatic Aristocracy" (Sociological Theory 2017), and "Expanding Moral Panic Theory to Include the Agency of Charismatic Entrepreneurs" (British Journal of Criminology 2018). He is currently researching the ongoing social protests in Hong Kong.

Robin Willey is Assistant Professor of Sociology at Concordia University of Edmonton. He has previously published articles that focus on Evangelical Christianity in Canada and on social theories of religion, such as "Liminal Practice: Pierre Bourdieu, Madness, and Religion" (2016) and "Shifting the Sacred: Rob Bell and the Postconservative Turn" (2019). His most recent research investigates the changing theo-political orientations and practices of Canadian Evangelicals and faith-based humanitarians. 